\title{
PRIMARY SEDIMENTARY FEATURES IN KITTILÄ JASPER, FINNISH LAPLAND
}

\author{
KINNUNEN, KARI A.
}

\begin{abstract}
KINNUNEN, KARI A. 1982: Primary sedimentary features in Kittilä jasper, Finnish Lapland. Bull. Geol. Soc. Finland 54, 1-2, 69-76.

Primary sedimentary features of Precambrian iron-formations in the Kittilä greenstone complex have been preserved as ghosts in jasper. The primary features represent clastic texture with tabular and oval clasts of red ferruginous chert in a matrix of white chert. The clasts are composed of seven texturally different types that show reworking and indicate weakly consolidated sediments as their provenance.
\end{abstract}

Kari A. Kinnunen, Geological Survey of Finland, Kivimiehentie 1, SF-02150 Espoo 15, Finland.

\section{Introduction}

Cherty metasediments of Precambrian iron-formations often contain well-preserved primary sedimentary features, which in many cases may provide a tool for paleoenvironmental interpretations, e.g. Dimroth (1968); Paakkola (1971); Gross (1972); Dimroth (1976); Laajoki and Saikkonen (1977); Barley et al. (1979); Gross (1980); and Gole and Klein (1981). In this paper, the primary sedimentary and early diagenetic textures are described and their sedimentology interpreted from the jasper (ferruginous red chert) of the Vuossavaara occurrence in Hanhimaa, Kittilä. Because of their deep red colour, these jaspers have found use as gem material under the name » Kittilä jasper».

The jasper occurrences in Kittilä were noticed by Hackman (1925) and classified as Precambrian iron-formations by Mikkola (1941). They form lenses 2-10 $\mathrm{m}$ wide and
20-200 $\mathrm{m}$ long in mafic metavolcanic rocks with pillow and agglomerate structures (Lehto and Niiniskorpi 1977). The mafic metavolcanic rocks predominate in the Kittilä greenstone complex, considered in some parts Archaean (Rastas 1980). Jasper clasts have been observed in the Kumpu conglomerate (Laitakari 1967, p. 294), which is interpreted as Lower Proterozoic (Rastas 1980). This mode of occurrence proves the Proterozoic age of the jasper lenses and may indicate their Archaean origin.

\section{Methods}

The textures were sought on polished slabs with a hand lens and a stereomicroscope and finally studied in thin sections in transmitted and dark-field reflected light under an ore microscope. The grain sizes of the textural components were measured from the thin sections with an ordinary microreader; those 


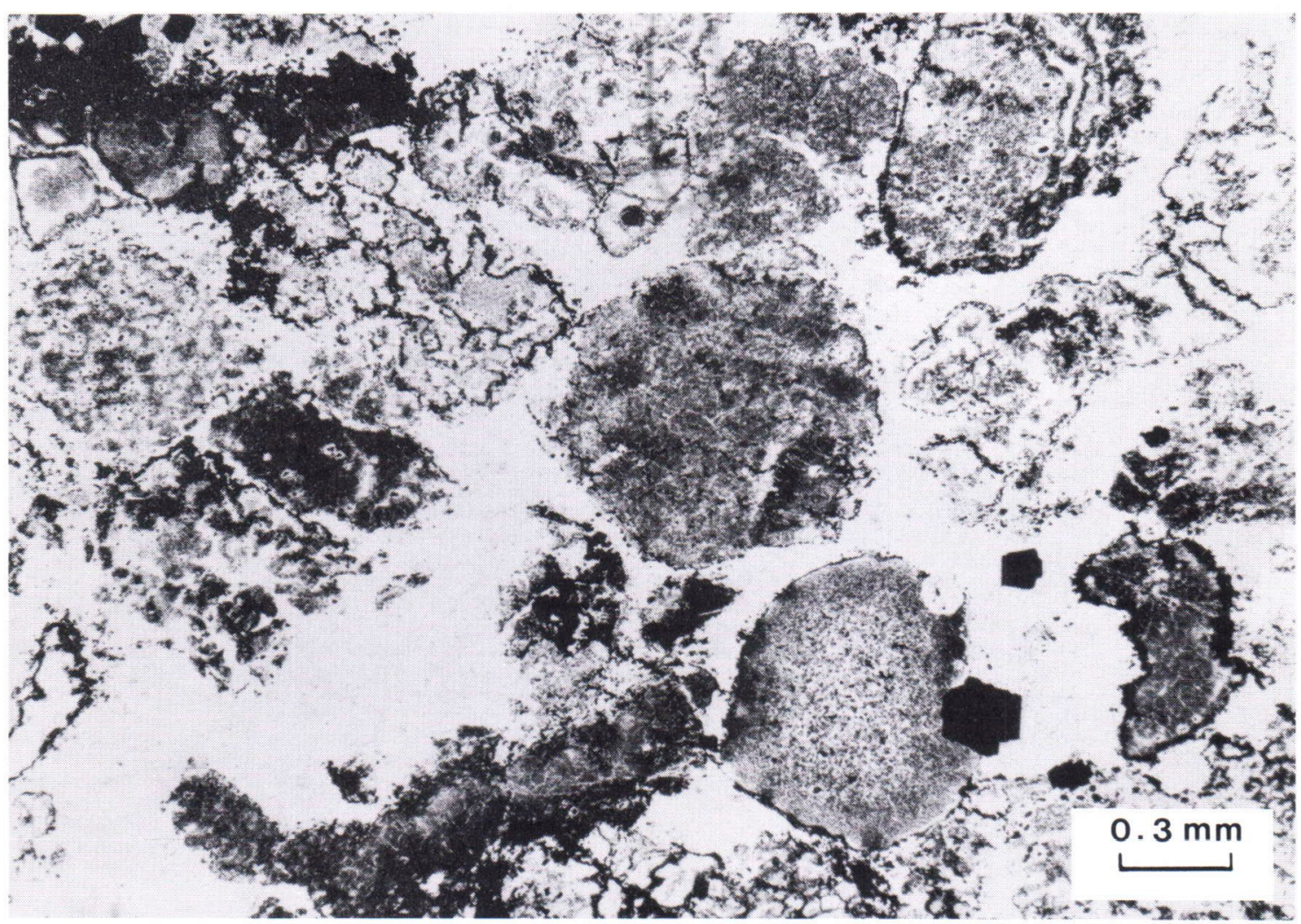

Fig. 1. Photomicrograph showing the polymictic clastic texture of the Kittilä jasper. Transmitted light, thin section 22371. Photo by Erkki Halme.

of the mineral components were measured under the ore microscope equipped with an ocular screw micrometer.

\section{Textures}

Kittilä jasper consists mainly of finegrained quartz with inclusions of minor hematite. Although the jasper is recrystallized, ghosts of primary textures are preserved in hematite dust. Early diagenetic processes have redistributed the hematite dust to some degree and formed the diagenetic inner textures of the clasts.

The primary textures of most of the jasper samples from Kittilä have been obscurred and in places totally destroyed by compaction and recrystallization connected with diage- nesis and low-grade metamorphism (Kinnunen 1979). Early diagenetic textures include recrystallized chalcedony spherulites and shrinkage cracks. The grain size of the microcrystalline quartz increased during metamorphism, and quartz veins with carbonate inclusions cutting the primary textures were formed.

The smallest grain sizes of quartz and hematite generally occur in areas containing well-preserved primary textures. There are two varieties of quartz: the cherty quartz as small polygonal grains (mean diameter 0.03 $\mathrm{mm}$ ) and the secondary quartz as larger grains (mean diameter $0.2 \mathrm{~mm}$ ) in the quartz veins and in the strongly recrystallized areas. The main hematite varieties are the hematite crystalloids of the hematite dust (diameter up to 
GRAIN SIZE IN MM

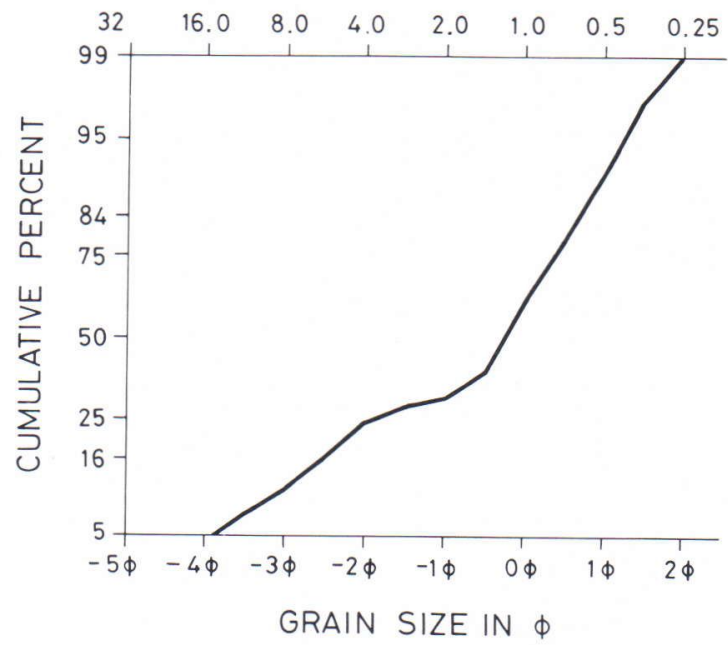

Fig. 2. Grain size frequency distribution curve for 205 well-preserved clasts (maximum diameters measured from thin sections and polished slab surfaces).

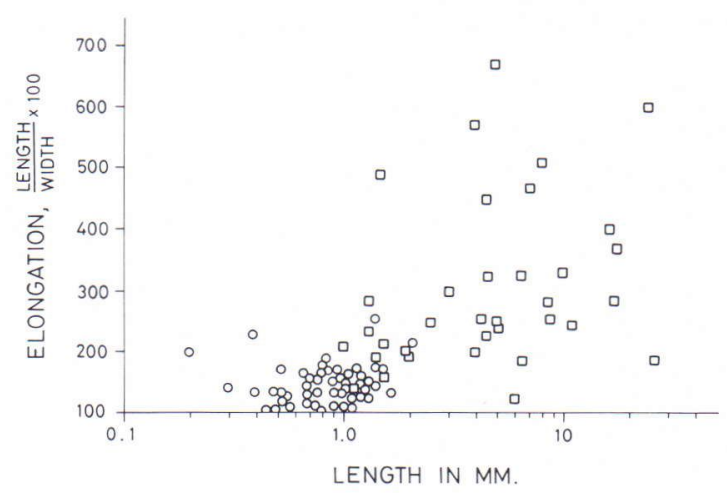

Fig. 3. Correlation between the size and shape of the clasts: $\bigcirc$ oval granules, $\square$ tabular bed fragments.

$1 \mu \mathrm{m})$ in the primary textured areas, the specularitic hematite occurring as larger tabular crystals (mean diameter $0.01 \mathrm{~mm}$ ), and the hematite aggregates forming the martitized magnetite octahedrons (mean diameter $0.25 \mathrm{~mm}$ ).

Kittilä jasper shows a pronounced blastoclastic texture in which the detrital components of red chert are embedded in a homogeneous matrix of white chert (Fig. 1). The detri- tal components can be classified as two types: tabular bed fragments and oval granules. Both clast types lie parallel to a weak planar orientation resembling bedding.

The grain-size distribution of the clasts (Fig. 2) has two populations: saltation and surface creep (or rolling population), the coarse truncation point being at about -1.0 phi units (cf. Visher 1969). The saltation population is mainly composed of granules and the coarser grained surface creep or rolling population of bed fragments.

The shape of the clasts correlates with their size (Fig. 3). The largest bed fragments are very elongated, whereas the granules are rounded and small, with a maximum average diameter of $1 \mathrm{~mm}$. The bed fragments show indistinct, usually gradual boundaries against the matrix, and some of the granules are pressed into their surface. Most of the granules and some of the bed fragments with abundant hematite dust are undeformed. The granules are commonly irregular in outline but a few of them are of a regular flat discoidal shape. It is suggested that the granules, too, are bed fragments in origin, but that they are more abraded.

Most of the detrital components should be classified as intraclasts, because their similar mineral composition and texture indicate derivation from the same basin. The intensity of the red colour of the intraclasts correlates to the amount of hematite dust. Two per cent of the clasts are yellow green. These may be extraclasts, that is, they derive from outside the basin proper. Only iron-formation material was observed as clasts; not a single detrital mineral grain, e.g. quartz, feldspars or heavy minerals, was noted.

The intraclasts can be subdivided into seven texturally different types (Table 1). The bed fragments exhibit different percentages of textural types from the granules.

The spheroidal type (Fig. $4 \mathrm{~A}$ ) is pink and the predominant textural type of the bed 


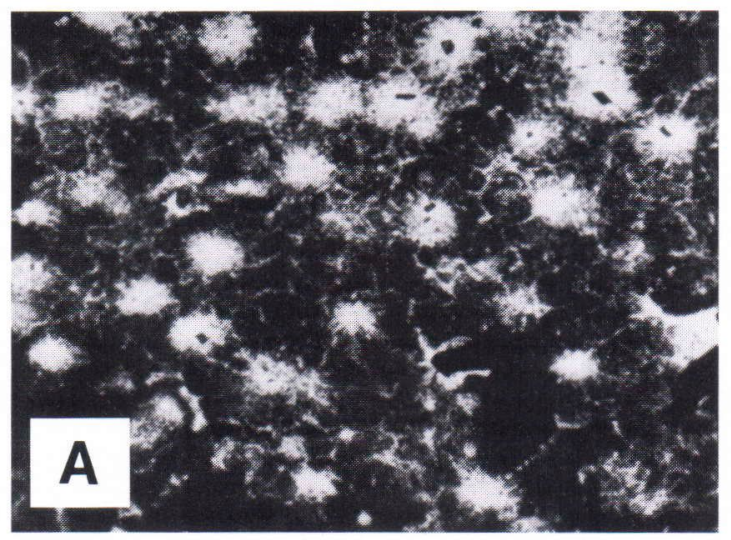

-

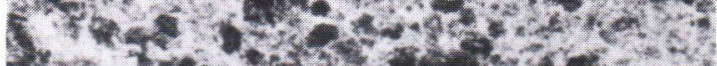

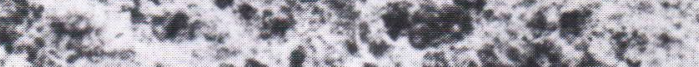

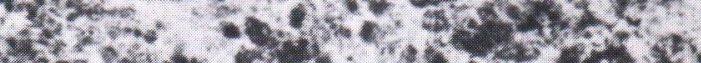

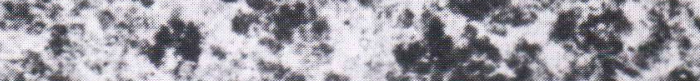

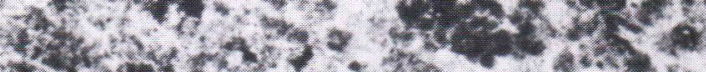

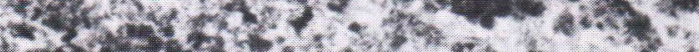

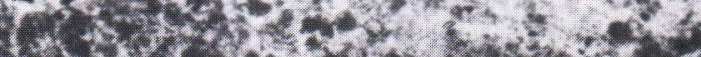

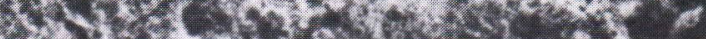

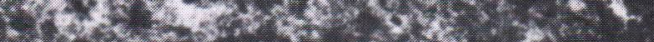

\section{B}
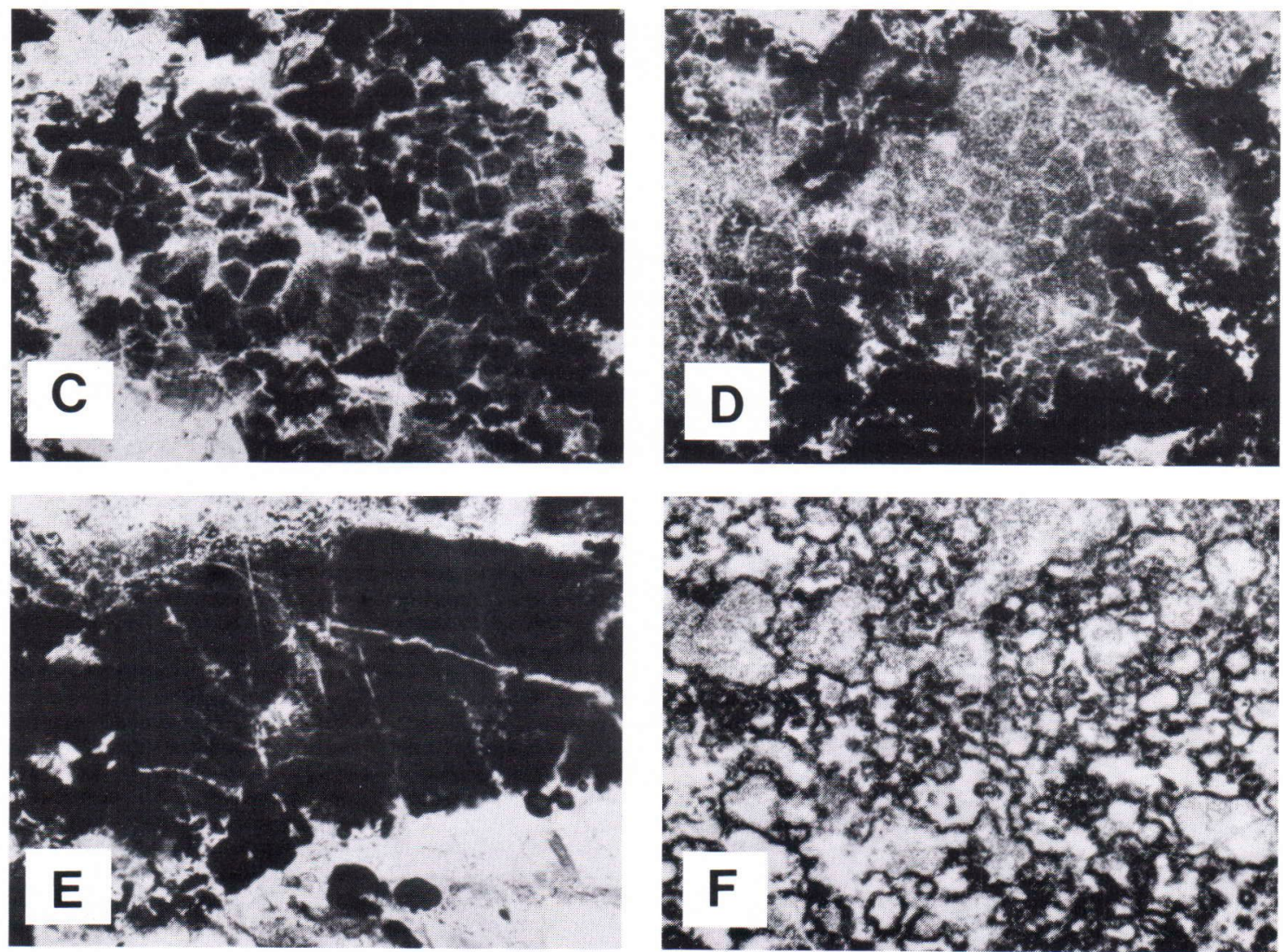

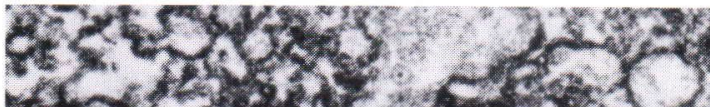

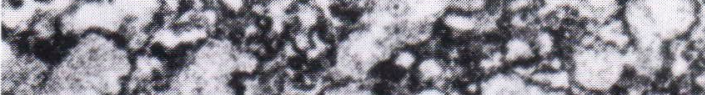
C 35 .

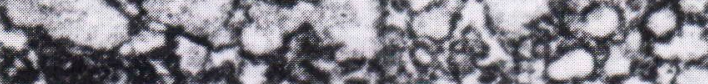
$8+2$ d. 3 .

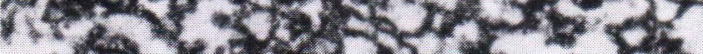

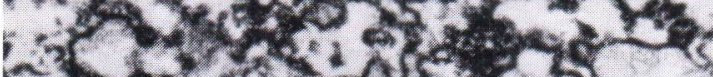

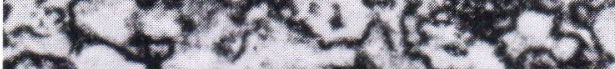

5 F
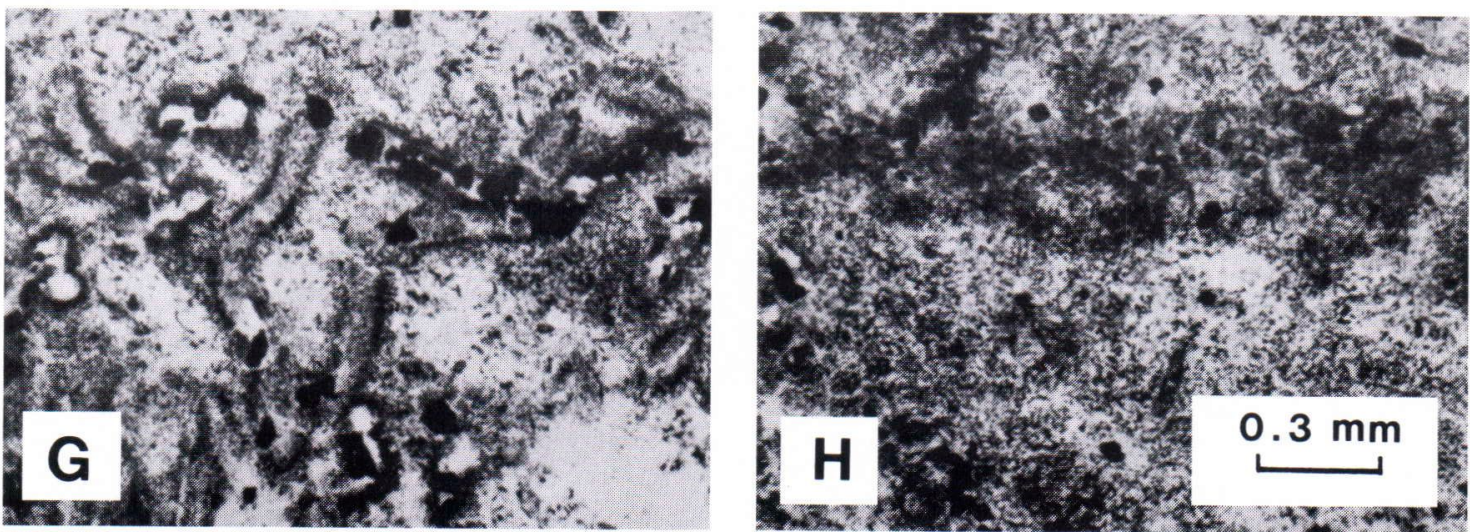
Table 1. Clast types in the Kittilä jasper.

\begin{tabular}{lcc}
\hline Textural type & \multicolumn{2}{c}{ Number percent } \\
\hline Bed fragments & Granules \\
\hline Baneroidal & 33 & 65 \\
Massive I & 16 & - \\
Massive II & 3 & 28 \\
Colloform & 15 & 7 \\
Tubular & 15 & - \\
Banded and & 12 & - \\
spheroidal & & - \\
\hline Sum & 6 & 100 \\
\hline
\end{tabular}

Data from 76 texturally well-preserved intraclasts.

fragments and granules. It is characterized by spheroids free of hematite dust and each hosting in its centre one specularite crystal. This type was fragmented into polygons. The spheroids may represent relict spherulites of chalcedony, because, in some of them, the quartz crystals are radially oriented (see Kastner 1979, Fig. 2). A similar texture has been described as a spherulitic texture by Spencer and Percival (1952, Figs. 10, 14-18). The type with tiny hematite crystals is analogous to the assumed microfossils described by LaBerge (1973) from the chert of banded iron-formations. A similar texture has also been described by Dimroth and Chauvel (1973, Fig. 7 B) from the cherts of Sokoman Iron Formation, Canada. They (ibid.) likewise interpreted these textures as relics of globular aggregates of chalcedony.

The banded type (Fig. $4 \mathrm{~B}$ ) includes only pink bed fragments. A few of the clasts contain ghosts of granules, which indicate an earlier stage of transportation, deposition and compaction preceding the reworking. Some of the clasts contain stylolitic seams between the beds, suggesting that diagenetic solution already existed in the source beds, i.e. in the weakly consolidated iron-formations. Similar banded textures have been described by other authors, e.g. Spencer and Percival (1952, Figs. 1 and 3).

The massive type (Fig. $4 \mathrm{C}, \mathrm{D}$, and $\mathrm{E}$ ) is deep red and occurs more frequently as granules than as bed fragments. It can be classified into two subtypes: I, the homogeneous type (Fig. $4 \mathrm{E}$ ); and II, the type with dehydration cracks (Fig. 4, C and D). Subtype I also contains cracks, but the two subtypes differ in fracturing. Subtype I was fractured in a brittle state and thus the fractures do not form triple junctions at angles of $120^{\circ}$ but with two angles approaching $90^{\circ}$. Subtype II was fractured in a plastic state, most probably by dehydration. In this type the cracks meet at triple junctions with angles approaching $120^{\circ}$. Bleaching has affected some of the subtype II clasts and only traces of hematite dust remain (Fig. 4 D). Subtype II is texturally similar to the polygonal textures formed by recrystallization of quartz (see Spencer and Percival 1952, Figs. 7 and 8; and Dimroth 1968, Plate 23, Figs. 3 and 5).

The colloform type (Fig. $4 \mathrm{~F}$ ) occurs only as reddish brown bed fragments. It consists of globular areas free of hematite dust that is enriched in their rim. The hematite has been recrystallized as specularite in these globular areas. This type often forms coatings on bed fragments composed of the massive type. The porosity of the colloform type is indicated by the frequent involution of granules into this type of material. The globular areas resemble the gas-expansion holes frequently observed in recent muds (cf. Reineck and Singh 1973, p. 217).

The tubular type (Fig. $4 \mathrm{G}$ ) occurs only as reddish-brown bed fragments. It consists of

Fig. 4. Photomicrographs showing the main textural types of the larger well-preserved intraclasts: A spheroidal, B banded, C, D and E massive, F colloform, G tubular, and $\mathrm{H}$ combined banded and spheroidal. Plane polarized transmitted light, thin sections 22281 and 22371. 
vermicular tubes free of hematite dust, but generally there is a specularite crystal at both ends of the tube. The tubes are surrounded by a rim of hematite dust as in the colloform type. The tubular type forms porous coatings on bed fragments of other textural types. Nevertheless, it also forms individual bed fragments, suggesting its deposition, or early diagenetic origin, in the source formations. In a few bed fragments the tubes are filled with hematite and surrounded by a zone of clear quartz.

The banded and spheroidal type (Fig. $4 \mathrm{H}$ ) occurs only as pink bed fragments. It consists of banded fragments within which there is a steady impregnation of quartz spheroids free of hematite dust but with one large specularite crystal. A similar texture has been described by Spencer and Percival (1952, Fig. 16).

\section{Chemical indications}

The Kittilä jaspers were interpreted by Mikkola (1941) and Paakkola (1971) as hot spring sinter deposits, probably associated with greenstones. According to the spectrographic determinations by Sahama (1945), the almost total absence of trace elements from the red jasper of Kapsajoki, Kittilä, is consistent with the sinter interpretation. According to the analytical data on cherts of various origins (Lovering 1972), the scarcity of trace elements suggests that the Kittilä jaspers were not formed as a jasperoid by replacement of a precursory carbonate rock. This notion is supported by petrographic observations indicating the absence of carbonate and gypsum pseudomorphs, ooid-like grains and oncolithic overgrowths (cf. Barley et al. 1979).

The analyses published by Lehto and Niiniskorpi (1977, p. 28) reveal that the total iron content of the Kittilä jaspers is under 20 per cent Fe. The hematite-quartz assemblages of the Precambrian banded iron-formations, however, are characterized by a constant iron content with an average of about 38 per cent Fe (Eichler 1976, p. 185). This uniform iron content in all of the Precambrian banded iron-formations is indicative of their origin as colloidal iron-hydroxide and silica precipitates, because artificial colloidal iron and silica precipitates are characterized by the same ratio of iron to silica (ibid.). In the Kittilä jaspers the low total iron content may be attributed to leaching of the clasts during reworking.

\section{Depositional environment}

The primary sedimentary textures in the individual clasts of the Kittilä jasper show that the material was deposited in the source beds as chemical precipitates and as colloidal flocculates. Reworking of these beds is evidenced by the polymict clastic texture composed of tabular bed fragments and oval granules with different inner textures. The sedimentary character of the Kittilä jasper together with field evidence of pillow and agglomerate structures in the surrounding metavolcanic rocks points to interflow chemical deposits. According to Lowe (1980), thin cherty metasediments intercalated with ultramafic-mafic metavolcanic sequences are typical of Archaean and Proterozoic greenstone belts. In the opinion of Barley et al. (1979), these interflow deposits usually belong to the initial phases of the development of volcanic sequences.

Iwao (1970) has interpreted ferruginous silica rock deposits from the Palaeozoic geosynclinal basins of Japan as submarine post-volcanic deposits. Their chemical composition (ibid., Table 2) and the manner of the later vein-quartz brecciation (ibid., Fig. 5) closely resembles the Kittilä jasper. If the lenses of the Kittilä jasper were likewise precipitated onto the submarine basalt lava floors above hot spring wells, they may be 
compared to recently discovered submarine hydrothermal mounds. On the Galapagos Rift these mounds form rows almost parallel to the spreading axis. In height they vary from less than a metre to over $20 \mathrm{~m}$; in length they constitute continuous ridges 100 to 200 $\mathrm{m}$ long (Corliss et al. 1979). The mounds are formed when warm fluids flow up along fractures from the basaltic crust and precipitate iron and silica onto the sea floor.
Acknowledgements. The author wishes to thank Mr. Reijo Alviola, Mr. Seppo Hornytzkyj, F. G. A., Dr. Tapio Koljonen, Mr. Hannu Ollila, and Dr. Risto Tynni for generously supplying samples of foreign cherts, Mr. Erkki Halme for taking the photomicrograph in the Figure 1, Mrs. Helena Halme for processing the photographs, Mr. Jouko Pääkkönen for preparing the thin sections, Mrs. Rauha Tapanainen for copying the illustrations for printing, and Mrs. Gillian Häkli for correcting the English text.

\section{References}

Barley, M. E., Dunlop, J. S. R., Glover, J. E., and Groves, D. I., 1979. Sedimentary evidence for an Archaean shallow-water volcanic-sedimentary facies, eastern Pilbara Block, western Australia. Earth Planet. Sci. Lett. 43, 74-84.

Corliss, J. B., Dymond, J., Gordon, L. I., Edmond, J. M., von Herzen, R. P., Ballard, R. D., Green, K., Williams, D., Bainbridge, A., Crane, K., and van Andel, T. H., 1979. Submarine thermal springs on the Galápagos Rift. Science 203, 1073-1083.

Dimroth, E., 1968. Sedimentary textures, diagenesis, and sedimentary environment of certain Precambrian Ironstones. N. Jb. Geol. Paläont. Abh. 130, 247-274.

Dimroth, E., 1976. Aspects of the sedimentary petrology of cherty iron-formation. In Wolf, K. H. (ed.) Handbook of stratabound and stratiform ore deposits. Vol. 7, pp. 203-254. Elsevier, Amsterdam.

Dimroth, E. and Chauvel, J.-J., 1973. Petrography of the Sokoman Iron Formation in part of the Central Labrador Through, Quebec, Canada. Geol. Soc. Amer. Bull. 84, 111-134.

Eichler, J., 1976. Origin of the Precambrian banded iron-formations. In Wolf, K. H. (ed.) Handbook of stratabound and stratiform ore deposits. Vol. 7, pp. 157-201. Elsevier, Amsterdam.

Gole, M. J. and Klein, C., 1981. Banded ironformations through much of Precambrian time. J. Geol. 89, 169-183.

Gross, G. A., 1972. Primary features in cherty ironformations. Sediment. Geol. 7, 241-261.

Gross, G. A., 1980. A classification of iron formations based on depositional environments. Can. Mineral. 18, 215-222.

Hackman, V., 1925. Porkosen-Pahtavaaran rautamalmikentän geologiasta. Geotekn. Julk. No. 39, Suomen Geologinen Komissioni, Helsinki 41 p.

Iwao, S., 1970. Clay and silica deposits of volcanic affinity in Japan. Pp. 267-283 in Volcanism and Ore Genesis, T. Tatsumi (ed.). University of Tokyo Press, Tokyo, 448 p.

Kastner, M., 1979. Silica polymorphs. In: Marine Minerals, R. G. Burns (ed.) Mineralogical Society of America, Short Course Notes, Vol. 6, Washington, Chapter 3.

Kinnunen, K. A., 1979. Kittilän jaspiksen kvartsin sulkeumista. Geologi 31, 28-30.

Laajoki, K. and Saikkonen, R., 1977. On the geology and geochemistry of the Precambrian iron formations in Väyrylänkylä South Puolanka area Finland. Geol. Surv. Finland, Bull. 292, $137 \mathrm{p}$.

LaBerge, G. L., 1973. Possible biological origin of Precambrian iron-formations. Econ. Geol. 68, 1098-1109.

Laitakari, A., 1967. Suomen mineraalien hakemisto. Index of finnish minerals with bibliography. Bull. Comm. géol. Finlande 230, 842 p.

Lehto, T. and Niiniskorpi, V., 1977. Pohjois- ja Itä-Suomen rautamuodostumat. Summary: The iron-formations of northern and eastern Finland. Geol. Surv. Finland, Report Invest. No. 22,49 p.

Lovering, T. G., 1972. Jasperoid in the United States - its characteristics, origin, and economic significance. U.S. Geol. Surv. Prof. Paper 710, $164 \mathrm{p}$.

Lowe, D. R., 1980. Archean sedimentation. Ann. Rev. Earth Planet. Sci. 8, 145-167. 
Mikkola, E., 1941. Kivilajikartan selitys B7-C7-D7, Muonio - Sodankylä - Tuntsajoki. English summary: Explanation to the map of rocks. General Geological Map of Finland, 1 : 400000 . Helsinki, 286 p.

Paakkola, J., 1971. The volcanic complex and associated manganiferous iron formation of the Porkonen - Pahtavaara area in Finnish Lapland. Bull. Comm. géol. Finlande 247, 83 p.

Rastas, P., 1980. Stratigraphy of the Kittilä area. In Silvennoinen, A. (ed.) Jatulian geology in the eastern part of the Baltic Shield. Proceedings of a Finnish-Soviet symposium held in Finland, 21st - 26th August, 1979, pp. 145-151. The Committee for Scientific and Technical
Co-operation between Finland and the Soviet Union, Rovaniemi.

Reineck, H.-E. and Singh, I. B., 1973. Depositional Sedimentary Environments. Springer, Berlin, 439 p.

Sahama, Th.G., 1945. Spurenelemente der Gesteine im südlichen Finnish-Lappland. Bull. Comm. géol. Finlande 135, 86 p.

Spencer, E. and Percival, F. G., 1952. The structure and origin of the banded hematite jaspers of Singhbhum, India. Econ. Geol. 47, 356-383.

Visher, G. S., 1969. Grain size distributions and depositional processes. J. Sed. Petrol. 39, 10741106.

Manuscript received, April 4, 1982 